\title{
LEVERAGING RURAL LIVELIHOODS WITH FOREST CONSERVATION IN NIGERIA: THE ROLE OF NON-TIMBER FOREST PRODUCTS
}

\author{
Egbe BASSEY ETOWA *1 ${ }^{1}$, Osim Eyam OJOGU ${ }^{2}$, Samuel Sunday ODUNLAMI ${ }^{3}$
}

\author{
Address: \\ ${ }^{1}$ Department of Agricultural Economics and Extension, University of Port Harcourt, Choba, Rivers State, Nigeria \\ ${ }^{2}$ Department of Agricultural Economics,University of Nigeria, Nsukka, Nigeria \\ ${ }^{3}$ Department of Forestry and Wildlife Management, University of Port Harcourt, Choba, Rivers State, Nigeria \\ *Corresponding Autor, email: egbetowa@yahoo.com, egbe.etowa@uniport.edu.ng
}

\begin{abstract}
In recent times some economists view Non-Timber Forest Products (NTFPs) extraction and marketing as a better alternative to timber exploitation as a rural livelihood strategy. Harvesting and sale of NTFPs have the potential for accomplishing the dual goals of natural forest conservation and income generation for the rural inhabitants. Meanwhile, realization of these dual goals in Nigeria, require an understanding of how NTFPs functions in the face of marketing, ecological, geographic and institutional constraints. Following a conceptualization of NTFPs, this paper provides a vivid overview of the simultaneous roles of NTFPs in rural livelihood enhancement and forest conservation in Nigeria. It highlights governmental initiatives with respect to conservation, the challenges and prospects of NTFPs as a conservation strategy. Conclusively, the paper suggests that appropriate NTFPs development policies are required to simultaneously address forest depletion and poverty in rural areas of Nigeria.
\end{abstract}

Key words: forest, non-timber forest products, conservation, rural, livelihood JEL: Q56

\section{INTRODUCTION}

Non-Timber Forest Products (NTFPs) are 'all thebiological material that may be extracted from natural ecosystems, managed plantations, etc., and be utilised within the household, be marketed, or have social, cultural or religious significance. Wickens (1991) in: Neumann and Hirsch (2000) defined such biological material regarded as NTFPs to exclude industrial round wood and derived sawn timber, wood chips, wood-based panels and pulp. Similarly, Adepoju and Salau (2007) defined NTFPs as plants or plant parts that have perceived economic or consumption value to encourage their collection and removal from the forest. FAO (2008) gave it a more comprehensive definition; as forest materials derived from soil mineral, water, fauna and flora resources other than round wood (sawn wood).

Thus, NTFPs are classified into non-wood and nontimber products. The non-wood products are derived from wild animals; meats, skins, horns, bones and teeth (Rai and Uhl, 2004). Most often, non-wood products include herbs, bark, roots, tubers, corms, saps, resins, gums, flowers, latex, honey, ropes, fungi, forage, gravel, clay, limestone and natural salt (Rai and Uhl, 2004). The woody but non-timber products include poles, charcoal, rattan canes, sponge, chewing sticks, bamboos and others. NTFPs include animal and plant products excluding timber and fuel wood. Another classification of NTFPs includes edibles and non-edibles. Depending on it source of harvest or collection, NTFPsF can be grouped into wild stocks (from unmanaged forest), managed stock (from managed forest) or domesticated stock (from an agricultural system). Ladipo (2008) identified uses of NTFPs as for food, fodder, fibre, medicine or traded to generate income.

Iloeje, (2001) grouped the country into (A) forests and (B) savanna zones. These two major zones were further sub-divided into three zones each such as (A) Forests that consist of (i) salt-water swamp, (ii) freshwater swamp, (iii) high forest; and (B) Savanna zone that consist of (i) guinea savanna (ii) Sudan savanna, and (iii) Sahel savanna. However, Oyenuga (1967) classified Nigeria into nine (9) agro-ecological zones viz:- (i) The mangrove forest and coastal vegetation, (ii) the freshwater swamp communities, (iii) the tropical high forest zone, (iv) the derived Guinea savanna with relict forest, (v) the Southern Guinea savanna zone, (vi) The northern Guinea savanna zone, (vii) The Jos plateau, (viii) The Sudan savanna, and (ix) The Sahel savanna. All the nine ecological zones, from the mangrove forests in the south to the Sahel in the far north of Nigeria are rich in diverse flora and fauna species (Ladipo, 2008).

In the rainforest belts flora NTFPs such as Rattan cane (Calamus calamus), Bush pepper (Pipper guinesis), Aligator pepper (Aframomum melegueta) and African Salad (Gnetum africana) are commonly found. The varied ecological zones in the country also provide shelter for different wildlife species. Thus, the country is blessed with abundance wildlife species used for consumptive and non-consumptive purposes. They also constitute a great deal of commodities offered for trade 
thereby promoting commercial activities at the rural level. Some of the popular wildlife species of touristic value in Nigeria National Parks and Zoos include Elephant (Loxodonta Africana), Buffalo (Syncerus caffer), Lion (Panthera leo), Crocodile (Crocodilus niloticus). Others include: Baboons (Papio anubis), Waterbuck (Kobus defassa), Warthog (Phacocoerus aethiopicus), Hippopotamus (Hipotragus amphibious) Western Hartebeest (Alcelaphus buselaphus) and Bushbuck (Tragelaphus scriptus).

There are indications that the NTFPs sector is growing faster than the timber industry, and it is expected to grow more in the future. This rapid growth is linked to the fact that NTFPs are important items of cross-border trade in the humid forest zone of West and Central Africa (Malleson, 2001). Outcomes from NTFPs trade in local, regional and international markets contributes significantly to rural livelihoods. They further contribute to rural livelihood by providing critical supplies of food during seasons when agricultural crops fail or are otherwise scarce (Rai and Uhl, 2004). Aside these, NTFPs contributes a significant portion of daily food consumption in rural households. Because uses of forest are inevitable among the rural populace considering the role its play in their survival, it becomes necessary to adapt a pattern of use that does not comprise forest conservation drive. Therefore, the harvest and sale of NTFPs by rural communities is suggested as a possible solution to the often observed conflict between forest use and forest conservation.

Wollenberg and Belch (2001) saw that the availability of forest resources accessible to poor people and with potential for commercial development presents an opportunity to involve rural people in improving their economic options. Therefore, through intervention that strengthen rights to manage and harvest NTFPs, and that improve skills to manage and market those NTFPs, poor rural communities can be enfranchised. NTFPs development can be a stepping stone to forest conservation, economic empowerment of the poor, and support a broader socio- economic development.

In 2010, the Federal Ministry of Environment of Nigeria (FME) highlighted several existing initiatives to foster to realization of the prospects of the NTFPs. In 1970, the Federal Department of Forestry of Nigeria was established to coordinate forestry and conservation activities throughout the country. The department's vision has been "to ensure that $25 \%$ of the total land area of Nigeria is brought under sustainably managed forest cover. This vision aimed at producing forest resources (flora and fauna) in perpetuity and foster environmental stability”. Thus, the central aim of national forestry policy is to ensure biodiversity conservation and one of its guidelines includes the development of NTFPs.

In order to sustain the benefits of NTFPs in Cross River State, Nigeria for example, forest communities have by-laws regulating land tenure, access rights, forest clearing and bush burning. Additionally, the by-laws regulate watershed protection and water poisoning, timber extraction, NTFP collection, and trapping and hunting endangered species (One Sky, 2006). There are also Cross River State Forestry Codes of 1999. Community members appeared to be largely aware of State forestry laws and laws against killing endangered species. Cross River State also established Forest Management Committees (FMCs) to co-opt local communities into the management of reserve areas mainly to control forest exploitation.

In spite of the great potentials of NTFPs development and commercialization, there is a course for concern in Nigeria. The rapid population increase has meant that demand for NTFPs in Nigeria outstrips national supplies (Malleson, 2001). The domestication of some species of NTFPs have been encouraged to augment the national supplies from the forest ecosystem. Because domestication is underway, complimentary and more easily implemented forest management option is neceassry. Accomplishing the dual goals of natural forest conservation and income generation for the rural inhabitants requires an understanding of how NTFPs extraction and marketing functions in tropical regions (Shankar, Murali, Shankar, Ganeshaih and Bawa, 1998). This paper critically narrates the existing policies and possibilities for leveraging forest dependents households' livelihood with conservation through development of NTFPs in Nigeria.

\section{FOREST IN NIGERIA}

World Bank (2010) estimates put Nigerian population at 151.21 million (2.3 percent annual growth rate) in 2008; 78, 141,389.6 was a rural population (IFAD, 2010) and has a total land area of 9223, 768 square kilometres. Nigeria is situated within the tropical rainforest belt; forestland covers 102,700 square kilometres (11.12 \%) of the total land area of 9223, 768 square kilometres. Contrastingly, 86.2 percent agricultural land forestland (World Bank, 2010).

Nigeria lost about $95 \%$ of its forest cover making her a net importer of timber. Protected areas were set up by government to curb the menace of deforestation and to ensure forest sustainability. Such protected areas include: national parks e.g. Cross River National Park in order set up in 1991. The national park is a apropos because the huge diversity of plant life, many endangered animal species live there, including gorillas, leopards, chimpanzees, forest elephants and drill monkeys. Other protected areas include forest reserves. The Okomu forest reserve is one of the largest forest block covering an area of $1081 \mathrm{~km}^{2}$ in Edo State, about $50 \mathrm{~km}$ west of Benin City, Nigeria. Games reserves including the Yankari Game reserve were as well established to conserve forest resources.

\section{FOREST CONSERVATION EFFORTS IN NIGERIA}

According to Ojating and his Students (1997) before the advent of Western religion and education, local people spent much of their time learning traditional law enforcement from the elders. Some wild animals are believed to be emblems of clans or people. For example, 
in many communities, it was taboo to kill an elephant, land snails, crocodile, the West African Python. These animals are tabooed and very rarely killed. Pregnant women are not allowed to eat the meat of wildlife species, such as the tortoise, which have features and traits that the elders would not like transferred to offspring.

Certain wild trees were traditionally never cut down, and plants are often believed to have supernatural powers since the gods and spirits of the land and communities are said to live in the trunks of large trees. These beliefs were of immense potential benefit to the society as they allowed for the conservation of the forests, land and wildlife. The many wildlife species that are in existence today may provide evidence of the effectiveness of the taboos placed on them by our ancestors. The crisis started in 1914 when Nigeria became one entity by the amalgamation act. In addition to new religions, formal legal systems were established, and a formal police force to enforce the new law. In 1960, Nigeria gained political independence from Britain, and in 1967-1970, there was a civil war. Soon after the war, the oil boom years (in the 1970s/80s) brought a lot of revenues to Nigeria. The boom also meant mass migration of youths from rural areas to the big cities. This severed the links between the villages and urban centres, and between the elders and the youths. Both formal and traditional laws became difficult to enforce (Ojating and his Students, 1997).

According to the Cross River Rural Participatory Forestry Project (1994) in Ogar (2008), the village chiefs use youth organizations to restore authority. The chiefs also use age groups, powerful traditional institutions and women's organizations to restore the authority. These institutions protect their forests and place sanctions on disturbed land. The youth organisations are dynamic and formulate policies for the village council (chiefs, elders, age-group leaders, women leaders and youth leaders). The key to this is that these youths act in accordance with the rules and dictates of folklore. This folklore was the foundation of traditional societies in terms of values and customs. The weakening of the culture and traditional beliefs which were advantageous in terms of conservation wild species no doubt necessitate government interventions.

According toFME (2010) the main thrust for forestry development and natural resources conservation is to provide the policy framework for the sustainable utilization and management of forest resources nationwide as well as ensuring that available natural resources are utilized sustainably. Equally important is the evolution of programmes and strategies for the rational use, management and conservation of the nation's natural resources.

The defunct Forest Management, Evaluation and Coordinating Unit (FORMECU), was set up to monitor the implementation of the World Bank Forestry II Project. The unit hosted the data bank for Environmental Forestry Management and carried out Forestry Resources Studies. At the expiration of the project, the Unit was transferred back to Federal Department of Forestry, its parent Department (FME, 2010).
In 1970, the Federal Department of Forestry was established to coordinate forestry and conservation activities throughout the country. Its functions are to initiate and formulate national forest policy and foster forestry and environmental development. The Department's role was also to promote and fund projects of national interest. It also coordinate and monitor Federal Government/donor supported forestry and conservation initiatives in the States as well as ensuring institutional development.

The Department has Field Offices in all the 36 States of the Federation including one in Gwagwalada in the Federal Capital Territory. The field offices liaise with the State Forestry Departments on forestry, conservation and environmental matters in general and they also ensure effective implementation and monitoring of federal government supported forestry and conservation projects (FME, 2010). Each of the Field Offices has at least an office building, labour lines, stores and standard Nursery with Nursery Shed that has capacity for raising 1 million seedlings. Thus, these Field Offices can raise about 50 million seedlings of assorted type annually if the existing labour forces are judiciously used to full capacity in these outstations (FME, 2010).

Other facilities available include the Sawmilling and Wood Utilization Centre in Benin City, Forest Industry Unit in Ibadan and a host of other training facilities at Forestry Manpower Development Centre (FMDC), Oluwa, Ondo State (currently being managed by the College of Forestry, Ibadan and University of Ibadan, for practical experience for Forestry Graduates) and the Vocational Training Centre (VTC), Kano. The Department was transferred from the Federal Ministry of Agriculture and Rural Development to the Federal Ministry of Environment in 1999 by a Presidential directive and restructured with some new mandates (FME, 2010). The new mandate include to ensure, coordinate and enforce forestry conservation for sustainable production of forestry goods and services

According to FME (2010), the National Forestry Development Committee (NFDC) is the highest technical committee that acts in an advisory capacity to government on all forestry matters in Nigeria. Membership comprises of Federal Director of Forestry as Chairman, States Directors of Forestry, Executive Director of the Forestry Research Institute of Nigeria, the Conservator-General of the National Parks Service and Heads of Forestry Departments in Universities. The Forestry Association of Nigeria (an NGO) is also a member of the Committee. A new National Forest Policy was approved by the Federal Executive Council in June 2006. The new policy was ratified by the National Economic Council (NEC) in October 2008 to be domesticated by all the States in Nigeria (FME, 2010). The major thrusts of the policy are poverty reduction, promotion of food security, environmental and biodiversity conservation in addition to sustainable production of wood and non-wood products (non-timber forest products). The policy is also to be backed up by the enactment of the first ever National Forest Legislation. The draft National Forestry Act has been 
forwarded to the Federal Ministry of Justice for finetuning. The States are encouraged to use these two forest management tools as models in reviewing their respective state forest policy and legislation.

\section{FOREST CONSERVATION AND NTFPs}

Conservation of resources involves management of the human use of natural resources to provide the maximum benefit to current generations while maintaining capacity to meet the needs of future generations. Conservation includes both the protective and rational use of natural resources (Submeter, 2008). Conservation is sometimes used synonymously with "protection". More appropriately, however, it refers to the protection and sustainable use of resources. Critical elements of the effective conservation of natural resources includes sustainable resource management, establishment one as, and ex-situ (offsite) conservation (Submeter, 2008). Scarcity of natural resources would eventually lead to diminishing social and economic returns to human efforts and ultimately to stagnation, retardation and cessation of socio-economic growth. The preceding assertion is the principle of natural resources conservation credited to some classical economists like Malthus (1798), Ricardo (2004) and Mills (1821). The accelerating deterioration of the resources base in much of Sub-Saharan Africa threatens to reduce production.

Extraction of NTFPs is a potential strategy to stem the rate of deforestation. This strategy is appropriate because of the recent high demands for timber and expansion of agricultural activities. However, the problem of forest sustainability still exists because of the increasing evidence that NTFPs - harvest/trade in practice does not follow the concept of good extractivism. Good extractivism is an approach of NTFPs collection that preserves the national forest while enhancing income (Almeida, 1996 in: Rai and Uhl, 2004).

The law of supply states that, all else assumed equal, higher prices induce greater production and offers to sell more output; firms provide less during a given period at lower prices. The law implies that with increasing market integration of forest products with its resultants increase in value, collectors and marketers of forest products will invest more of their leisure hours in its extraction and sale. However, the effect of this on sustainable forest conservation is complex. Supposing that forests contain a mix of tradable, substitutable and non-tradable goods (i.e., not all forest goods have a market). With progressive integration into the market, households reduce investment in substitutable and inferior nontradable forest products, and continue to reallocate their labour to production of tradable forest products (Wilkie and Godoy, 1996). This market integration leads to increasing specialisation with trade. This specialisation results in a reduction in the evenness of diversity of forest goods extracted by households.

Household investment will focus on a declining number of forest goods that will contribute an increasing share to household income. Though households are investing more in fewer goods, trade theory predicts only that investment in substitutable and inferior non-tradable goods will decline, not that investment will, necessarily, cease (Wilkie and Godoy, 1996). Thus, although the relative intensity of extraction of forest goods may change, the absolute number or variety of forest goods extracted may not change. With increasing trade, exploitation of forest-based exportable and superior nontradable goods will intensify, and their abundance will decline. Large, slow-growing, slow-reproducing species will be more prone to local extinction than small, fastgrowing, rapidly reproducing species.

High market value and efficient technology have the potential, however, of causing the local extinction of any forest-based exportable good. The preceding assertion was drawn from works of de Beer and McDermott (1989); Schmink, Redford and Padoch (1992) in: Wilkie and Godoy, (1996). As a forest-based good becomes progressively rare with over-exploitation for export, the market for this good may change as consumers find cheaper, more-abundant substitutes (Homma, 1992).

\section{SUSTAINABILITY OF NTFPs}

A resource use rate that is sustainable does not mean that resources must remain untouched, rather, it means that their rates of use are planned such that they do not endanger future generations. In the absence of rational and conscious sustainable exploitation of physical and natural resources, irreplaceable or probably irreversible damages inevitably result (Olajide, 2003). In relation to agriculture, sustainability means changing agricultural systems so that farmers can produce indefinitely (Rai and Uhl, 2004). Hence, sustainable agriculture should be based on approaches that reduce environmental degradation, conserve resources, and provide an adequate and dependable farm income through reducing poverty and associated problems (Eze, 2009). Similarly, sustainable marketing of NTFPs should adopt such approach.

Sustainability stems from that which meets the needs of the present without compromising the ability of future generations to meet their needs (Cataula, 2002). Contextually, it is the ability of the forest to produce food, fodder, fibre, medicine, employment and income indefinitely without irreversible damage to the forest ecosystem.

It entails successful management of forest to meet human needs while ensuring sustainability of the quality and quantity of the forest resources. A popular approach to ensuring sustainability is by putting value on the NTFPs. When NTFPs are valued, the intensity of logging could be reduced and dependence on NTFPs increased, domestication encouraged, and forest conservation enhanced (Igreeens, 2006). Based on this idea, the extraction of NTFPs was widely proposed as a strategy to simultaneously stem the rate of deforestation and rural poverty (Nepstad and Schwartzman, 1992 in; Rai and Uhl, 2004). Harvesting of certain NTFPs are sustainable in Tamanada Forest Reserve in Cameroon which is a major source of NTFP to Nigeria (Sunderland, Besong 
and Ayeni, 2003) (Table 1). Sustainability of NTFPs is a case in point for the role of NTFP in forest conservation.

On contrary, however, some studies reported that ecological effects of NTFPs harvest/trade were higher than expected. The lack of security of tenure, a situation commonly encountered in state controlled forests, often results in adverse ecological impacts such as damage during harvests and suppressed regeneration (Rai and Uhl, 2004). Rapid population increase in Nigeria has meant that Nigerian demand for NTFPs outstrips national supplies. This rapid population growth without commensurate increase in NTFPs contributes to the degradation in Nigeria's forest. For example, commercial demand for Gnetum due to rapid population growth has driven wild populations of this leafy vine to almost local extinction (Wilkie, Godoy, 1996 and Clark, 2001). Therefore, control over Gnetum use and harvest levels is a desideratum. Substitution or domestication may also be an alternative way to conserve this product without adversely affecting local livelihoods (Clark, 2001).

Sustainable use of NTFP from Iringa tree goes beyond not logging the trees. Sustainable use involves safeguarding of the plants to ensure adequate yield in its season. It also entails ensuring that the genetic resources of the species are adequately consumed and protected (Ladipo, 2008). Enrichment plantings that will support the ecological status of the forest and also enhance the productivity of irvingia kernels are necessary for this sustainable use. Also, the establishment of pure commercial plantations will help and ensure sustainable production of irvingia in Nigeria. This sustainable production will be feasible at the reduction of pressure on the natural forest as population and external demand grow (Ladipo, 2008).

\section{SEASONALITY OF NTFPS}

Although harvesting and sale of many non-timber forest products happens all year round, seasonality is an occasional phenomenon in some of these products. Seasonality often creates economic gap in the livelihood system for many forest dependent communities and have substantial effects for household welfare. Hence, realization of the full potential of NTFPs in forest conservation and livelihood enhancement requires that the effects of seasonality on its availability be effectively managed through appropriate NTFPs Development Programmes.

The impact of seasonality on bush mango is high as it often available only between June to september and Febraury to April depending on variety (Table 2). Meanwhile, bush mango is a NTFP of high economic value. Also, seasonality has moderate impacto on year round availiability of certain NTFPs including eru, chewing stick, bush pepper and bush onion (Table 2).

\section{ROLE OF NTFPS IN RURAL LIVELIHOOD ENHANCEMENT}

Research undertaken as part of the Overseas Development Administration (ODA) assisted project enumerated the significant roles of NTFPs trades in the socioeconomic wellbeing of rural communities in Cross River State (CRS) of Nigeria (Sunderland, 2001 in: Chukwuone, 2008). Millions of households do not only depend on NTFPs to supplement their domestic requirements of food, fodder, fibre and medicines. They also depend on NTFPs to supplement their incomes by selling part, or all, of their collection in local markets. Thus, NTFPs are consumed in rural and urban homes, and are traded in local, regional and international markets. NTFPs also provide part -time employment for hundreds of millions of people who work in small-scale forest industries (Wollenberg and Belch, 2001).

Particularly, NTFPs often play critical roles as safety nets for poor rural households. At the same time, wealthy households with access to agricultural markets often consume NTFPs or buy them from the poor collectors for sale. Thus, NTFPs play significant roles in both poor rural and rich urban households. As a subsistence good, NTFPs supplement inputs of fuel, food, medicinal plant products, etc. from the farm system (Arnold and Perez, 2001). The products are important in filling seasonal and other food gaps, particularly in hard times; forest foods enhance palatability of staple diets, and provide vitamins and proteins. Arnold and Perez (2001) further viewed that NTFPs can be important in diversifying the farm household economy. For example, they provide counterseasonal sources of food, fodder and income. Also, important in providing a reserve that can be used for subsistence and income generation in times of hardship (crop failure, drought, shortage of wage employment, etc), or to meet special needs (school fees, weddings, etc. Irvingia spp and Gnetum spp are some of the most important NTFPs in terms of their respective contributions of $58.9 \%$ and $23.3 \%$ to total household (Figure 1). The economic relevance of Irvingia spp in Nigeria cannot be overemphasized. An estimate of annual collection of irvingia fresh fruits from the high forest zones of Nigeria stood at 750,000 tons (Ladipo, 2008). Meanwhile, an estimated collection and drying of irvingia seeds from all sources stood at 120,000 tons per annum (Ladipo, 2008). Thus, over 1.2 million tons of Irvingia are marketed in Nigeria, which represents about 40 percent of West African total annual production (Ladipo, 2008).

There exists extensive trade in the kernels of Irvingia within southern rainforest area. The trade also interconnects the southern rainforest and the northern savannah areas of Nigeria (Ladipo and Boland, 1994). The kernels are transported to the North of Nigeria by wholesale traders, and these are traded internationally to various other countries (Ladipo, 1998). Commercial development of this produce shows its importance in the economy of its collectors/harvesters.

Omoluabi and Abang (1994) estimated a combined export trade volume of 72231mt valued at N339.04 million (US\$ 1.6822 million at March, 2015 exchange rate) for nine NTFPs in Cross River State (CRS). These nine NTFPs include: gnetum, irvingia, garcinia, randia, bushmeat, pole, capillobia and flitches. Of the nine NTFPs, they estimated returns on investments in gnetum 
trade for various groups in the marketing chain. The percent returns on investments were: $33 \%$ for collectors, 75.7\% for wholesale buyers who export outside of CRS. Wholesale buyers who distribute within CRS had 33\% whereas retailers who sell within CRS had 30\%. Retailers who export outside CRS had $15.8 \%$ as returns over investment.

On the national front, a total of 607862.5 metric tons of gnetum traded between 2002 and 2008, valued at about 1,262,334.7 USD internally generated revenue (IGR). This sum accrued to the economies of Cameroon and Nigeria and return to investment was $57 \%$ for its harvesters (Fuashi, Popoola, Mosua, Wehmbazeyi, Louis and Elah, 2010).

Compared to other highly valued forest products such as timber, trade in gnetum, for example, touches the life of more people in the rural areas. It generates income for a wide range of people who otherwise are left out from benefiting from the exploitation of the forest. It provides job for eligible youths at all stages of the process of harvesting, loading, transportation, etc. Even children in Cross River State often spend 3-5 days in the forest searching and collecting gnetum. The proceeds from the sale of these NTFPs are often used to pay their school fees and to meet their other basic needs (Anukwa, 2003). Clark (2001) found that Gnetum africanum leaves sell for $\$ 0.47 / \mathrm{kg}$, which, is almost three times the price of bitter leaf (Vernonia amygdalina) in Europe and United States. He also found that the Africa, diaspora in
Europe and United States are willing to pay US\$ 50/kg for air-freighted gnetum.

Wildlife as a class of NTFPs contributes significantly to the livelihood of households domiciled in the forested areas. Utilisation of wildlife in these areas includes its consumption for medicinal purposes especially (trado-medicinal purpose). Also, wildlife often serves as sources of protein and meat in many communities in the forested areas of the country. The non-consumptive utilisation of wildlife in Nigeria is primarily for tourism especially in national parks and zoos. These parks and zoos spread across the country are mostly situated in forested areas thereby creating livelihood for the rural inhabitants through paid employment. More significantly, wildlife contributes to rural households incomes through trade. Studies by Aiyeloja and Ajewole (2006) found that bushmeat trade do not only provide livelihoods through reasonable marketing margins, they also provided equitable distribution of this income among the trade participants.

For example, on the bushmeat, wholesaler genarates returns on a 3000 Nigerian Naira (NGN) from a cost of 2280 Naira whereas the bushmeat hunter makes retuns of 1800 Naira from an input cost of 840 Naira (Figure 2). Hence, per cent gross profit accuing to the poor and forest based hunter (53.3\% of revenue) is greater than (24\% of reveue) accruing to the relatively richer and perhaps urban based wholesaler.

Table 1: Sustainability of Selected NTFPs

\begin{tabular}{|c|c|c|c|}
\hline Resource & $\begin{array}{l}\text { Part } \\
\text { Harvested }\end{array}$ & $\begin{array}{l}\text { Impact of Harvesting on } \\
\text { sustainability }\end{array}$ & Level of sustainability \\
\hline Bush mango & Fruit & Low & $\begin{array}{l}\text { Relatively sustainable, good regeneration and community-level } \\
\text { cultivation }\end{array}$ \\
\hline Eru & Leaves & $\begin{array}{l}\text { Low to medium } \\
\text { to high (depending on } \\
\text { technique) }\end{array}$ & $\begin{array}{l}\text { Relatively sustainable if leaves are plucked, and the stem is not cut, but } \\
\text { destructive unsustainable harvesting is often undertaken }\end{array}$ \\
\hline $\begin{array}{l}\text { Chewing } \\
\text { stick }\end{array}$ & Bole & High & $\begin{array}{l}\text { Highly unsustainable; species has limited geographical range and is in } \\
\text { danger of extinction over the long term }\end{array}$ \\
\hline Bush pepper & $\begin{array}{l}\text { Leaves } \\
\text { and } \\
\text { fruits }\end{array}$ & Moderate & $\begin{array}{l}\text { Relatively sustainable if leaves and fruits are plucked and the stem is } \\
\text { not cut }\end{array}$ \\
\hline Hausa stick & stem & High & $\begin{array}{l}\text { Highly unsustainable because of removal of whole stem, including root } \\
\text { collar }\end{array}$ \\
\hline Rattan canes & $\begin{array}{l}\text { Mature } \\
\text { stems }\end{array}$ & Low to medium & Relatively sustainable at current levels ofHarvest \\
\hline
\end{tabular}

Source: Sunderland, Besong and Ayeni (2003)

Table 2: Impact of Seasonality on Availability of Selected NTFPs

\begin{tabular}{|c|c|c|}
\hline Resource & $\begin{array}{l}\text { Impact of } \\
\text { seasonality }\end{array}$ & Availability \\
\hline Bush mango & High & $\begin{array}{l}\text { Rainy season type (I. gabonensis ) available June to September; } \\
\text { dry season type (I. wombolu ) available February to April }\end{array}$ \\
\hline Eru & Moderate & $\begin{array}{l}\text { All year, although there is less plucking and reduction of } \\
\text { supply during early rains as people are occupied with farming }\end{array}$ \\
\hline Carpolobia Cattle stick & Low & $\begin{array}{l}\text { All year, although transportation problems in rainy season } \\
\text { restrict supply to markets }\end{array}$ \\
\hline Randia Chewing stick & Low & $\begin{array}{l}\text { All year, although transportation problems in rainy season } \\
\text { restrict supply to markets }\end{array}$ \\
\hline Garcinia chewing sticks & Moderate & $\begin{array}{l}\text { All year, although increased availability in rainy season } \\
\text { because of better boat access to remote creeks in forest }\end{array}$ \\
\hline Bush pepper & Moderate & Fruits produced in dry season; leaves can be harvested all year \\
\hline
\end{tabular}


Bush onion $\quad$ Moderate $\quad$ Fruits produced during rainy season, but after drying, they can be stored for some time

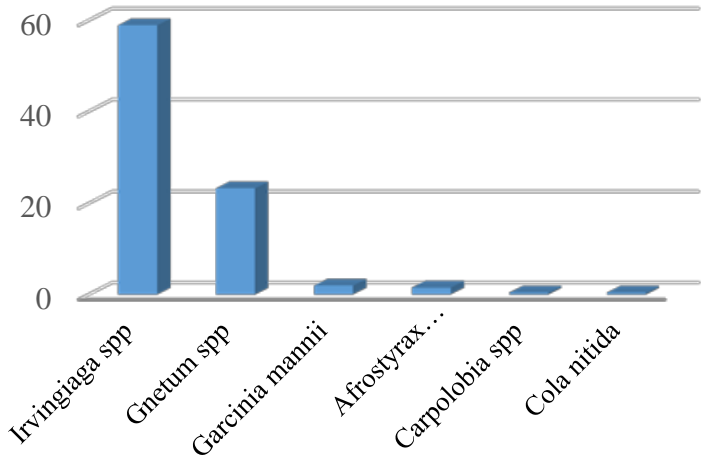

Figure1: Percent Income contribution by selected NTFPs from Takamanda, Cameroon but traded in Nigeria. Source: Authors derivation from Sundeland, Besong and Ayeni (2003)

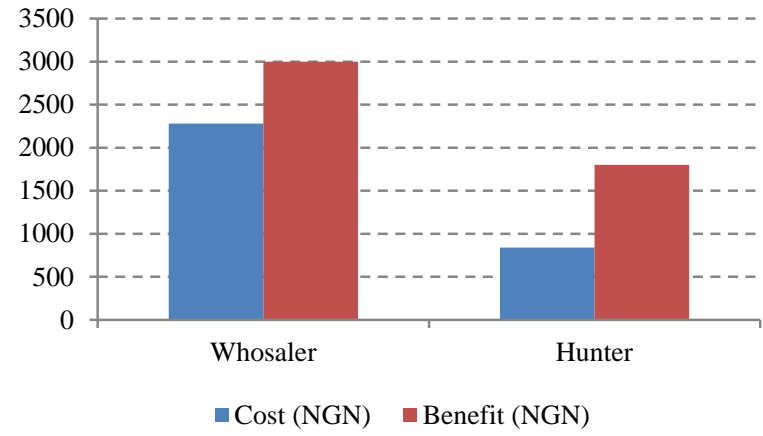

Figure 2: Cost and Return (Naira) per bushmeat hunter and wholesaler in Osun, State, Nigeria, 2006

Source: Derived by authors from Aiyeloja and Ajewole (2006)

Exactly $43 \%$ of the margins from trade accrued to wholesale bushmeat trader whereas $57 \%$ goes to the bushmeat collector (hunter) (Aiyeloja and Ajewole, 2006). This was a relative fair distribution of income, implying that the forest dependent households (poor NTFPs collectors or hunters) are not outpaced or left in poverty.

The economies of millions of households in the Asian Pacific region are forest driven. That is, they depend on forest products to supplement their incomes by selling part or all of their collection in local markets (Sial, 2008). Buttressing the preceding fact is the U.S experience. The U.S. exported about 77tons of wild harvested American ginseng valued at more than $\$ 21 \mathrm{~m}$ in 1993 (Foster, 1995 in: Adepoju and Salau, 2007). Two years earlier, Virginia exported about 6.5tons of the ginseng worth over \$1.8m (Adepoju and Salau, 2007). Rourke also affirmed that the U.S herbal medicine market grew at an estimated annual rate of $13-15 \%$ with sales of medicinal herbs. The market for forest products other than trees has boomed by nearly 20\% annually over the past years (New York Times, 1996 in: Adepoju and
Salau, 2007). These demonstrate that NTFPs play a significant role in the nation's economy.

\section{CHALLENGES AND PROSPECTS OF NTFPS DEVELOPMENT IN NIGERIA}

The numbers, types, population and diversity of species that occur in the ecological zones vary in accordance to inherent genetic characteristics, land use practices, edaphic conditions and environmental influences. The Nigerian NEEDS document identified critical issues relating to biodiversity conservation. These issues include; environmental degradation such as deforestation and desertification, weak enforcement of environmental laws including forest conservation policy. Other critical issues were: loss of biodiversity, inadequate environmental data including those of forest resources. Absence of a system of national accounting that captures the contribution of the environment including forest resources to development was also important problem. Clearly, sustainable conservation of NTFPs in Nigeria has not been possible due to several challenges.

More than $90 \%$ of NTFPs are prone to market failures and are, therefore not accounted for in GDP calculations. Most NTFPs are prone to market failures because they are treated as free goods, overused and degraded. Due to under-pricing, market prices do not reflect their full marginal opportunity cost to society ( FAO, 2008). Thus, the value of the forests in economic terms is only about $1.3 \%$ of the GDP calculations. Consequently, only close to $10 \%$ of the budgetary allocation to the agricultural sector is made available for forestry development.

Management of NTFPs is difficult to coordinate and harmonize at regional and national levels. Inadequate knowledge of species in terms of utilization, biology and ecology makes most of the NTFPs difficult to capture at the national level. Most of the NTFPs originate from species that occur from the wild. Conservation of the species is under in situ conservation programmes within the context of common property resource utilization. Common property resources are subjective to tenure systems in vogue in various communities (FAO, 2008). They are also subjected to taboos that determine their utilization, harvest, social acceptance and their various end uses, and to traditional and cultural user rights.

Nevertheless, prospects for forest and NTFPs conservation in Nigeria abound with clarity policies and right implementation of government programmes to develop NTFPs. Nigeria embarked on rural forestry development through the production and supply of seedlings to individuals and organisations (Uwechue, 2008). This forestry development was part of Nigeria's strategies to tackle the problem of desertification, including the improvement of the environment in arid zones. Nigerian Economic Empowerment and 
Development Strategies targeted the implementation of the national biodiversity strategy and action plan. It also targets the promotion of sustainable measures for reforestation and afforestation that fosters community based industry and improved food security. Furthermore, promotion of agro-forestry, promotion of wildlife farming, sericulture, apiculture, and the marketing of non-timber forest products were NEEDS targets. Finally, development and adoption of a system of national accounting that captures the economic contribution of the environment sector encourage the growth and adoption of aromatic and herbal plants for primary health care were vital components of NEEDS. The biodiversity goal also led to the establishment of The Federal Department of Forestry in 1970. Its functions are to initiate and formulate national forest policy and foster forestry and environmental development, promote and fund projects of national interest.

Futhermore, the department's role incuded: to coordinate and monitor Federal Government/donor supported forestry and conservation initiatives in the States as well as ensuring institutional development. The Department was transferred from the Federal Ministry of Agriculture and Rural Development to the Federal Ministry of Environment in 1999 by a Presidential directive. Since then the department's vision has been "to ensure that $25 \%$ of the total land area of Nigeria is brought under sustainably managed forest cover. The vision aimed at producing forest resources (flora and fauna) in perpetuity and foster environmental stability” (FME, 2010). Thus, the central aim of national forestry policy is biodiversity conservation, and one of its principal guidelines is the development of NTFPs.

Effort has also been made towards the development of forest plantation and forest protection to assist in the production of fuel woods, poles, gum arabic, shea butter and tanning plantations. There is a plan to protect the natural forest and the environment from fire. In fact, about 10 million tree seedlings were raised each year and distributed to communities and individuals. Decree 11 of 1985 under the United Nations treaties to which Nigeria is a signatory provides for the conservation and management of Nigeria's wildlife. The decree also provide for the protection of some animals in danger of extinction as a result of over-exploitation. It specifically prohibits the killing or trading of certain animals and restricts the exportation and importation of some animals, with stiff penalties (Uwechue, 2008). Also, as part of an effort to preserve our natural environment, Nigeria has Game Reserves in all the states of the Federation.

There have also been efforts from the private sector to preserve the life in our environment. The African Wildlife Society in Kenya and the Nigerian Conservation Foundation (NCF) is a private body concerned with preservation and protection of our environment. The NCF has embarked on a campaign designed to educate Nigerians on the judicious use of their natural endowment to foster its renewal for the succeeding generation.

\section{CONCLUSION}

Harvesting of NTFPs is a nature conservation strategy because it reconciles conservation and development. Also traditional laws and security of land tenure provides incentives to communities to conserve natural resources and the continued existence of biodiversity. NTFPs contribute considerably to rural people's sustenance and earnings. However, it should be noted that NTFP extraction is still mostly subsistence orientated, part-time and seasonal activity. Although they are not without challenges, many prospects exist for pro-poor forest activities to complement and strengthen key components of rural livelihoods. There is a pressing need to facilitate strategic interventions that will enable forest resources to play its full role in livelihoods through improved local forest governance.

- $\quad$ This participatory forest management or community forestry is a viable and sustainable forest (including NTFPs) management option because it will promote local roles and draw due attention to underlying forest tenure interests.

- A carefully planned domestication incorporated with extractive activities might help to check the orthodox boom-and-bust cycles of extractive economies, contributing to their long-term maintenance and providing room for a good tree cover.

- $\quad$ Stepping up NTFPs development through promotion of NTFPs farming will be an effective instrument for poverty reduction and sustainable management of natural resources

- Awareness creation on the nutritional, medicinal, and environmental benefits of NTFPs will significantly help to promote the farming of NTFPs

- Information diffusion, empowerment of collectors and creation of linkages between collectors and traders, will provide NTFPs market sellers access to market information thereby cubing inefficiencies in NTFPs markets.

\section{REFERENCES}

ADEPOJU, A. A. - SALAU, A. S. (2007). Economic Valuation of Non-Timber Forestry Products (NTFPs). Munich Personal RePEc Archive (MPRA) Paper No. 2689, posted 07. November 2007/ 02:40 Online at http://mpra.ub.uni-muenchen.de/2689

AIYELOJA, A. A. - AJEWOLE, O. I. (2006). Nontimber forest products' marketing in Nigeria. A case study of Osun state. Educational Research and Reviews Vol. 1 (2), pp. 52-58, May 2006

ALMEIDA, M.W.B. 1996. 'Household Extractive Economies', in M. Ruiz Perez and J.E.M. Arnold (eds), Current Issues in Non-Timber Forest Products Research: Proceedings of the Workshop Research on NTFP' Hot Springs, Zimbabwe, pp. 11942. Bogor, Indonesia: Center for International Forestry Research.

ANUKWA, F. A. 2003. Community Forestry for Improved Rural Livelihoods. Experience from Cross River State, Nigeria. In Proceedings of the $29^{\text {th }}$ Annual 
Conference of the Forestry Association of Nigeria held in Calabar. $6^{\text {th }}-11^{\text {th }}$ October

ARNOLD, J. E. M. - PEREZ, R. 2001. Can non-timber forest products match tropical forest conservation and development objectives? Ecological Economics 39 (2001) 437- 447. doi: http://dx.doi.org/10.1016/S09218009(01)00236-1

CATAULA, S. 2002. Some considerations on sustainable aquaculture pp. 22 - 26 In: B. Basurlo and M. Saroglia (compilers); Sea farming today and tomorrow. European Aquaculture society. Special published

CLARK, L. 2001. Non-Timber Forest Products Economics and Conservation Potential. Central African Regional Program for the Environment (CARPE): Congo Basin Information series, Issue Brief 10.

CONSTANIGRO, M. - MCCLUSKEY, J. J. MITTELHAMMER, R.C. 2007. Segmenting the wine market based on price: Hedonic regression when different prices mean different products. Journal of Agricultural Economics, 58 (3), 454-466. doi:10.1111/j.1477-9552.2007.00118.x

De BEER, J.H. - McDERMOTT, M.J. 1989. Economic Value of Non-timber Forest Products in Southeast Asia. Netherlands Committee for IUCN, Amsterdam

EZE, S. O. 2009. An economic study of farmland erosion control practices in Enugu State. M.Sc. Research Proposal. Department of agricultural Economics, University of Nigeria

FAO COPORATE DOCUMENT REPOSITORY. 2008. Non-Wood Forest Products in Nigeria. Retrieved April 9, 2008 from: www.fao.org.

FEDERAL MINISTRY OF ENVIRONMENT, NIGERIA (FME) 2010. Policy trust, vision, mission and mandate. Retrieved July 30, 2011 from the federal ministry of environment official website.

FOSTER, S. 1995. Forest Pharmacy: Medicinal Plants in American Forest. Forest History Society. Durham NC pg 57.

FUASHI, N. A.- POPOOLA, L.- MOSUA,I. S.WEHMBAZEYI, N. F.- LOUIS, N. N. - ELAH, E. M. 2010. Harvesting and marketing of Gnetum species (Engl) in Cameroon and Nigeria. Full Length Research Paper. Journal of Ecology and the Natural Environment Vol. 2(9), pp. 187-193

HOMMA, A.K.O. 1992. The dynamics of extraction in Amazonia: a historical perspective. Advances in Economic Botany 9: 23-31.

CHUKWUONE, N. A. 2008. Analysis of conservation and Utilization of non-wood forest products in Enugu and Cross River State; Unpublished Ph. D Thesis. Department of Agricultural Economics, University of Nigeria, Nsukka.

IFAD 2010. Enabling Rural People to Overcome Poverty. Federal Government of Nigeria: Country Strategic Opportunities Programme. IFAD Strategic Board-Ninety ninth Session.

IGREENS 2006. Marketing the non timber benefits of forests. Retrieved April 9, 2008 from: www.iGreens.org.uk.

ILOEJE, N. P. 2001. A new Geography of Nigeria. New Revised Edition. Longman Nigeria Plc. P.200
LADIPO, D. 2008. Harvesting of Irvingia gabonensis and Irvingia wombulu in Nigerian Forests; Potentials for the Development of Sustainable Systems. FAO Corporate Document Repository. Retrieved April 6, 2008 from: www.fao.org

LADIPO, D. O. - BOLAND, D. (1994). Trade in Irvingia kernels. Paper presented at International Workshop on Nigeria in West and Central Africa. International Centre for Research in Agroforestry (ICRAF)

MALLESON, R. 2001. Cross -Border Trade of NTFPs from the Korup Forest Area, Southwest Cameroon. European Tropical Forest Research Network ETFRN NEWS 32: NTFPs Organizations - Institutions Programmes

MALTHUS, T. R. 1798. An essay on the principle of population as it affects the future improvement of society (Methuen and Co. Ltd, London).

MILLS, J. S. 1821. On the principle of political economy and taxation ( $3^{\text {rd }}$ Edition). London.

NEPSTAD, D.C. - SCHWARTZMAN, S. (eds) . 1992. Non-Timber Products from Tropical Forests: Evaluation of a Conservation and Development Strategy. New York: New York Botanical Garden.

NEUMANN, R. P. - HIRSCH, E. 2000.Commercialization of Non-Timber Forest Products: Review and Analysis of Research. Center for International Forestry Research Bogor, Indonesia. with support from Food and Agriculture Organization of the Unite

NEW YORK TIMES, 1996. From Necessity, New Forest Industry rises. Sunday 24th March. National Report Section, Front page.United Nations (1995): Nonwood News. Writer Food \& Agricultural 17 Organisations Rome Italy.

OGAR, A. M. 2008. Performance of Forest Management Committees in the management of Forest Wood Trees in Cross River State. M.Sc. Research Proposal. Department of agricultural Economics, University of Nigeria, Nsukka OJATING, I. - THE STUDENTS OF FEDERAL UNIVERSITY OF AGRICULTURE, UMUDIKE. 1997. Folklore and conservation in Nigeria: using PRA to learn from the elders. PLA Notes, Issue 28, pp.22-24, IIED London

OLAJIDE, O. 2003. Step towards sustainable natural forest management for non timber in nigeria. Proceedings of $29^{\text {th }}$ annual conference of the Forestry Association of Nigeria held in Cross river state, Nigeria October 6-11, 2003).

OMOLUABI, A. C. - ABANG, S. O. 1994. Marketing margins in nontimber forest products trade in Cross River State of Nigeria. Cross River State Forestry Strategic Plan. Working Paper 12. Prepared for The Cross River State Forestry Project (ODA Assisted). Forestry Department Headquarters, Calabar

ONE SKY - CANADIAN INSTITUTE OF SUSTAINABLE LIVING AND CROSS RIVER ENVIRONMENTAL CAPACITY DEVELOPMENT COALITION. 2006. Cross River State Community Speak out: Cross River state Forestry Law: Policy Brief http://www.onesky.ca/files/uploads/Forest_Community Consultation_Policy_Brief_FINAL.pdf 
OYENUGA, V.A. 1967. Agriculture in Nigeria. Food and Agriculture Organization of the United Nations). FAO, Rome, Italy. 308 pp.

RAI, N. D. - UHL, C. F. 2004. Forest Product Use, Conservation and Livelihoods: The Case of Uppage Fruit Harvest in the Western Ghats. Conversation \& Society, 2, 2 SAGE Publications New Delhi/Thousand Oaks/London.

RICARDO, D. 2004. The principles of political economy and taxation. Mineola, NY: Dover publication.

SHANKAR, U.; MURALI, K. S.; SHANKAR, K.N.; GANESHAIH, K. S. AND BAWA (1998). Extraction of non timber forest products in the forest of Biligiri Ragan Hills, Indian 4. Impact on floristic diversity and population structure in a thorn scrub forest. Economic Botany. Vol. 52 (3): 302-315, July-Sept., 1998.

SCHMINK, M., REDFORD K. H. - PADOCH, . C. 1992. Traditional peoples and the biosphere: framing the issues and defining the terms, pp. 3-13. In Conservation of neotropical forests: working from traditional resource use, (eds.) Redford, K. H. and C. Padoch. New York: Columbia University Press.

SIAL, M. I. 2008. International trade in non timber forest products in the Asia Pacific region. FAO Corporate Document Repository. Retrieved April 6, 2008 from: www.fao.org

SUBMETER, W. 2008. Conservation of resources Scitech. Encyclopedia. Retrieved from: www.nationalexemption.com

SUNDERLAND, T. C. H.; BESONG, S. - AYENI, J. O. 2003. Distribution, Utilization, and Sustainability of Non-Timber Forest Products from Takamanda Forest Reserve, Cameroon. SI/MAB Series (8): 155 - 172, 2003
UWECHUE, T. 2008. The bio-environment - African dimensions. Retrieved July 30, 2011 from: http://www.biopolitics.gr/HTML/PUBS/VOL1/uwechue. $\underline{\mathrm{htm}}$

WICKENS, G.E. 1991 Management issues for development of non-timber forest products. Unasylva 42(165): 3-8.

WILKIE, D.S. - GODOY, R. A. 1996. Trade, indigenous rain forest economies and biological diversity model predictions and directions for research. in: Current Issues in Non-Timber Forest Products Research: Proceedings of the Workshop Research on NTFP held in Hot Springs, Zimbabwe 28 August - 2 September 1995.

WOLLENBERG, E. - BELCH, B. 2001. NTFPs- Income for Rural Populations Or Not? European Tropical Forest Research Network ETFRN NEWS 32: NTFPs Organizations - Institutions - Programmes.

WORLD BANK 2010. Nigerian Population. Retrieved January 10, 2012 from: http://data.worldbank.org/indicator/SP.POP.TOTL 